\title{
Translator's Foreword
}

The interface between artistic and socio-political activity is a pronounced feature of contemporary Latin American culture, hence it should come as no surprise that both the author and the subject of this book have been fervent participants in the literature and politics of twentieth-century Chile. It was poetry that brought Volodia Teitelboim and Pablo Neruda together as young men in Santiago, and it was as writers and political activists that they remained comrades and confidants for forty years, until Neruda's death in 1973, just two years after he received the Nobel Prize for literature and less than two weeks after the violent overthrow of Salvador Allende's Popular Unity government.

Teitelboim, who was a senator in that Allende government, never had any intention of writing a biography of Neruda, although he had published numerous articles and essays about the poet. Nonetheless, at the insistence of a Madrid publisher, he accepted the challenge of doing a book about the author whose own Memoirs had already been published. "My book," he says, "offers the perspective of someone who was very near to Neruda, but at the same time is capable of a historical distance denied to the individual who is talking about his own life." That perspective is apparent in Teitelboim's attempt to rescue Neruda from the pedestal of myth and allow him to again walk the streets of the world he loved so much.

Drawing on his own talents as an acclaimed novelist, Teitelboim has given us a biography that reads like a novel, presenting an intimate look at 
the poet and his work, from his humble childhood in what was then a frontier land in the south of Chile, through his bohemian youth as an impoverished university student in Santiago, his lonely existence in Southeast Asian consular outposts, his joyous discovery of Spain and his lifelong devotion to poetry, love, Chile and politics, ending with his unquiet death in 1973.

Volodia Teitelboim was born in 1916 in Chillán, in the Chilean province of Nuble. His university studies took him to Santiago, where he studied law, wrote poetry, read voraciously in several languages, and became active in journalism and politics. His first book, a historical study of the dawn of capitalism and the conquest of America, was published in 1943.

From 1947 to 1952, repressive measures by the González Videla government against leftist political figures forced Teitelboim and others, including Neruda, to go into hiding, and ultimately he was imprisoned in the Pisagua concentration camp. This same period saw the publication of two of his novels, Hijo del salitre (Nitrate's Child) in 1952, deemed a masterpiece among historical novels, and La semilla en la arena (Seed in the Sand) in 1957 (titled simply Pisagua in later editions). Both novels have been translated to more than six European languages.

In the following decades, Teitelboim gained prominence as one of the left's leading theoreticians and also served as Valparaíso's representative in congress and as Santiago's senator, a post he held until the military junta which masterminded the 1973 coup d'état stripped him of his Chilean citizenship and forced him into an exile that lasted for sixteen years. During that exile, he published his third novel, La guerra interna (Internal War) in 1979, critically hailed as an extraordinarily ambitious work which demonstrates the forces of continuity at work over a forty-year period of Chilean history, culminating in the violence unleashed in 1973 . It has also been published in German, Bulgarian, and Russian translations.

During his exile, which ended only in 1989 with a popular vote rebuffing General Augusto Pinochet's efforts to remain in power for an additional ten years, Teitelboim served as executive editor of the cultural journal Araucaria de Chile (Madrid) and wrote extensively on literary, historical and political themes, not only in scores of articles, collections of essays, and his biography of Neruda, first published in 1984, but also in an account of a secret trip he made to Chile in 1987 (En el pais probibido: Sin el permiso de Pinochet, In the Forbidden Country: Without Pinochet's Permission), as well as in a comparative study of Latin American and Russian/ 
Soviet literature (El corazón escrito, The Written Heart), published in 1986 in Moscow. His biography of Chile's first Nobel Prize poet, Gabriela Mistral, has just been published in Chile.

I should like to express my appreciation here to my friend and colleague Jack Schmitt, who first called my attention to this book and has generously offered his support and suggestions throughout.

In addition, it is a privilege to express my gratitude to Volodia Teitelboim for his constant collaboration and encouragement, not only from the outset of this project but most especially during my visit with him in Santiago in March 1989, shortly after he had finally been granted permission to return to his own country-a return still fraught with anxiety and insecurity in that precarious period, which only intensifies my appreciation for his generous availability.

I should also like to express my thanks to Inés Moreno in Santiago, Carlos Orellana in Madrid, and Claudio Teitelboim in Princeton; and to gratefully acknowledge support for this project from California State University, Long Beach, with special thanks to Karl W. E. Anatol, Dean of Humanities and now University Provost, and to the University's Scholarly and Creative Activity Committee.

And ultimately, my thanks to Franco Tonelli for tolerating and encouraging my sometimes frustrated but always optimistic attempts to stroke two languages and two cultures into an implausible but necessary coupling.

Beverly J. DeLong-Tonelli Laguna Beach, California 
THIS PAGE INTENTIONALLY LEFT BLANK 